Ebrié, Adjoudrou, Dido, Guerzé, and Kono. Several aspects of the political organization, economy, and ritual of the Kono, including demonstrations of the masked dances that accompany tribal initiation, were studied at Nimba.

The very arduous task of organizing, provisioning, and guiding this field party was undertaken by M. J. L. Tournier with the assistance of M. B. Holas, and deep gratitude was expressed for their tireless labours, kindness, and good humour.

An illustrated guide to the Ivory Coast, prepared in connexion with the Conference, provided concise surveys of its geography, resources, ethnology, economic development, and administration. It is hoped to make this available for more general distribution, and inquiries should be addressed to M. J. L. Tournier, Directeur, Centrifan, B.P. 398, Abidjan.

Owing to last-minute difficulties of time-table and transport the intended Portuguese participants in the Conference were unable to arrive. But their representatives on the Permanent Committee transmitted an invitation for the next meeting of the Conference to be held in December r95s in a Portuguese territory, probably at San Tomé.

The Conference at its final session recorded its deep appreciation of the generosity of the French authorities and of the labours of M. Tournier, Professor Mangenot and their colleagues in organizing the meeting and ensuring its success.

\title{
African History Conference
}

A CONFERENCE on African History was held at the School of Oriental and African Studies from 7 to 9 July 1953, under the chairmanship of Professor C. H. Philips, Head of the Department of History at the School. Among those who attended were representatives of the Institut Français d'Afrique Noire (IFAN), of the Musée du Congo Belge, members of the staffs of the African university colleges, and historians and archaeologists from universities in the United Kingdom.

The Conference was occupied with the two themes of oral tradition and historical archaeology, and with the practical problems arising from the development of these studies in Africa. Surveys of oral tradition in East, Central, and West Africa were used to show what conclusions about the movements of peoples and about chronology could be drawn from them at the present stage, and archaeologists described the progress of research into the problems of historical archaeology. It was clear from the discussions that both oral tradition and archaeology should make their contributions to such investigations as, for instance, the Uganda earthworks at Bigo and Ntusi.

Sir Mortimer Wheeler addressed the Conference on the organization of archaeological studies in Africa, and the Conference concluded with the passing of a number of resolutions urging the preservation of sites, monuments, and documents essential for reconstructing the outlines of African history. Attention was drawn to the need for expert and effective revision of existing Ordinances for preserving sites and monuments, and for the formation of adequately staffed departments of antiquities and record offices. As an immediate step, it was proposed that a School of History and Archaeology in East Africa should be established, which could act as a field training centre for students. The Kenya Government had undertaken to make Fort Jesus at Mombasa available for such a purpose.

In the concluding discussions, members expressed the hope that the Conference might meet at three- or four-yearly intervals.

\section{Communicated by R. A. Hamilton}

\section{The Gold Coast and Togoland Historical Society}

The Gold Coast and Togoland Historical Society was founded in 1952 in order to promote the study of history and, in particular, of the history of the Gold Coast and adjacent West 
African territories. In addition to an annual week-end conference of members, branch meetings are held from time to time at Kumasi and Cape Coast. The papers read at the inaugural meeting in January I9S 2 have been published in Volume I, part I, of the Society's transactions and include papers by Professor Varley on 'Castles and Forts of the Gold Coast' (illustrated by a number of excellent photographs), by Mr. Attafua on 'Traditional History', by Mr. Akita on 'Documentary material available for historical research in the Gold Coast', and by Dr. J. D. Fage, President of the Society, on 'Some general considerations relevant to historical research in the Gold Coast'. Dr Fage points out the urgent need for work to be done 'in the recording and elucidating of oral traditions, in the collection, preservation and interpretation of documentary material, and in research into the social and economic life of the country's past'. Until this work is done, no real understanding of Gold Coast history can be achieved.

\section{Institut International des Civilisations Différentes (INCIDI)}

LA $28^{\circ}$ session de l'INCIDI, tenu du 7 au Io septembre I953 à la Haye, fut consacrée à l'étude du relèvement rural dans les pays tropicaux et sub-tropicaux. La réunion avait été préparéeppar la distribution préalable à tous les participants de vingt-huit rapports spéciaux exposant les programmes et plans en cours ou projetés dans les territoires d'Afrique, d'Asie, d'Amérique du Sud et Centrale, rédigés par des experts de 16 pays, d'un rapport introductif préparé par Sir Bernard Binns de la F.A.O., et de trois rapports généraux. Les échanges de vues, auxquels participèrent plus de 80 personnalités de nombreux pays, furent immédiatement centrés sur les projets de conclusions contenus dans chacun des rapports généraux. Le travail poursuivi en séances plénières présidées par le Dr. P. J. Idenburg aboutit à l'adoption d'un certain nombre de résolutions concernant: (I) L'économie rurale, y compris la conservation des ressources naturelles, les obligations internationales dans l'assistance au développement, coordination des programmes de développement, la politique agricole nationale, les services agricoles; (2) Vie sociale rurale; (3) Politique et droit agraires; (4) Considérations sur le droit foncier. En outre quelques conclusions d'ordre général ont été formulées touchant l'insuffisance des études à ce sujet, la nécessité de tenir compte du facteur humain, de comprendre la mentalité des peuples intéressés et d'achever l'adhésion psychologique et la collaboration effective des populations dans tous les plans de développement rural.

\section{Agricultural Education in Uganda}

Ir is proposed to establish a Faculty of Agriculture at Makerere College, the University College of East Africa. The plan includes provision for teaching staff, a Faculty building with a laboratory and a university farm. A 340-acre holding ten miles from Makerere, as well as a herd of 60 Zebu-Ankoli cattle, have already been purchased for the university farm and a contour survey of the land has been started. The courses of instruction offered will be planned to enable students to enter for the London B.Sc. degree in agriculture.

As a complement to the Faculty of Agriculture, the Government of Uganda proposes to set up two Agticultural Institutes, one east and one west of the Nile, to provide practical training in modern methods of agriculture. These Institutes will be under the control of the Agricultural department and will include courses for departmental agricultural students as well as for farmers and cultivators. It is also intended to establish eight district Institutes providing less advanced courses for cultivators. 